\title{
Advantages and disadvantages of teleworking in Brazilian public administration: analysis of SERPRO and Federal Revenue experiences
}

\author{
FERNANDO FILARDI ${ }^{1}$ \\ RAChel Mercedes P. De CAStro ${ }^{1}$ \\ MARCO TULIO FUNDÃO ZANINI ${ }^{2}$

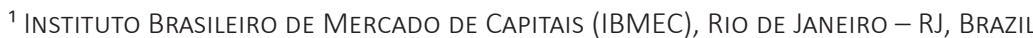 \\ ${ }^{2}$ Fundação Getulio Vargas (FGV EBAPE) / Escola Brasileira de AdMINISTRAÇÃo PúblicA E de EMpresa, Rio de JANEIRO - RJ, BRAZIL
}

\begin{abstract}
This study investigates the advantages and disadvantages of teleworking in public administration from the perception of 98 teleworkers and 28 managers at the Brazilian Federal Data Processing Service (SERPRO) and the Federal Revenue Service. Qualitative-quantitative research, consisting of questionnaires applied to teleworkers and interviews with managers, dealt with structural, physical, personal, professional, and psychological aspects. The results showed advantages such as better quality of life, work-family balance, greater productivity and flexibility, the possibility of creating standard metrics, better assessment of the workload, and reduction of costs, stress, commuting time, as well as less exposure to violence. As for disadvantages, the study identified elements such as non-adaptation, lack of communication and connection with the company, psychological problems, lack of infrastructure and control of the teleworker. The research concludes that teleworking requires a management model that makes it more adherent to the public sphere.
\end{abstract}

Keywords: Telework. Home-office. Labor relations. Public administration.

Vantagens e desvantagens do teletrabalho na administração pública: análise das experiências do Serpro e da Receita Federal

\section{Resumo}

Este estudo investigou as vantagens e desvantagens do teletrabalho na administração pública na percepção de 98 teletrabalhadores e 28 gestores do Serviço Federal de Processamento de Dados (Serpro) e da Receita Federal. Trata-se de pesquisa qualiquantitativa, composta por questionários aplicados aos teletrabalhadores e entrevistas com os gestores, que abordou aspectos estruturais, físicos, pessoais, profissionais e psicológicos. Os resultados evidenciaram como vantagens: melhoria da qualidade de vida; maior equilíbrio na relação trabalho x família; maior produtividade; flexibilidade; criação de métricas; redução de custo; estresse; tempo de deslocamento; exposição à violência; e conhecimento da demanda de trabalho. Já as desvantagens foram: não adaptação; falta de comunicação; perda de vínculo com a empresa; problemas psicológicos; infraestrutura; e controle do teletrabalhador. Conclui-se que o teletrabalho necessita de um modelo de gestão que o torne mais aderente à esfera pública.

Palavras-chave: Teletrabalho. Home-office. Relações de trabalho. Administração pública.

Ventajas y desventajas del teletrabajo en la administración pública brasileña: análisis de la experiencia del SERPRO y la Receita Federal

\section{Resumen}

Este estudio investigó las ventajas y desventajas del teletrabajo en la Administración Pública en la percepción de 98 teletrabajadores y 28 gestores del Serviço Federal de Processamento de Dados (SERPRO) y de la Receita Federal. La encuesta cuali-cuantitativa compuesta por cuestionarios aplicados a los teletrabajadores y entrevistas con los gestores abordó aspectos estructurales, físicos, personales, profesionales y psicológicos. Los resultados evidenciaron como ventajas: calidad de vida, equilibrio trabajo-familia, mayor productividad, flexibilidad, creación de métricas, reducción de costo, estrés, tiempo de desplazamiento, exposición a la violencia, y conocimiento de la demanda de trabajo. Por otro lado, las desventajas fueron: no adaptación, falta de comunicación, pérdida de vínculo con la empresa, problemas psicológicos, infraestructura, y control del teletrabajador. Se concluye que el teletrabajo necesita un modelo de gestión que lo haga más adherente a la esfera pública.

Palabras clave: Teletrabajo. Home office. Relaciones de trabajo. Administración pública. 


\section{INTRODUCTION}

Public administration is the subject of increasing debates in Brazil, regarding the state's size, legitimacy, efficiency, and performance. Society has demanded fast, quality public services and the use of information and communication technologies (ICTs) has contributed to responding to this request. In this context, there is a demand for new forms of service provision from the state, seeking greater efficiency to respond to the population's needs (FREITAS, 2008).

The Master Plan for the State Apparatus Reform (BRASIL, 1995) worked on the concept of efficiency of public administration, which is the need to reduce costs and increase the quality of services and was considered central in the reform. BresserPereira (2008) mentioned that one of the classic objectives of public administration is to protect the public assets, i.e., defend the res publica against private interests. Over the last decades, public administration has been increasingly related to the need to increase efficiency and agility, reduce costs and structure, and become more transparent and democratic (FARIA, 2009).

This study approaches teleworking considering this context. Teleworking has recently developed within private companies, as a consequence of the increasing use of information technology (IT), and has contributed to organizational flexibility and management processes (BOONEN, 2008), promoting greater efficiency in management. Also, according to the Brazilian Teleworking and Telemarketing Society (SOBRATT, 2016), among the advantages of teleworking are the reduction in the use of natural resources because of lower consumption in the workplace, improvement in the quality of life for workers, and better urban mobility as a consequence of fewer workers commuting. Data from the Brazilian Institute of Geography and Statistics (IBGE, 2010) show that about 20 million workers work from home.

However, there is little research on teleworking in the public sector. Thus, this study deepened the analysis of teleworking in public administration based on the perception of managers and teleworkers of public agencies in Brazil. The research approached the Federal Data Processing Service (Serpro), the Federal Court of Accounts (TCU), the Regional Labor Court of the State of Paraíba (TRT-PB), the Court of Justice of the State of São Paulo (TJ-SP), and the Federal Revenue Department. The only agencies that responded to the research and participated in the interviews were Serpro and the Federal Revenue Department.

The contribution of this research is to deepen the knowledge about the results of adopting teleworking in the public administration, from the perspective of managers and teleworkers, with the intention of promoting the expansion of this form of work to other public agencies, adjustments in the researched agencies and, contribute to design public policies on telework.

\section{LITERATURE REVIEW}

\section{The concept of teleworking}

Information technology (IT) is currently the main tool to support companies in their administrative and operational activities. It is one of the fundamental elements in improving the quality of products, services, and results of organizations, providing agility in well-defined bureaucratic processes, which has boosted teleworking in Brazil. The term 'telecommuting,' also known as 'home office' and 'teleworking,' was first presented by Nilles (1975).

For Rabelo (2000), telework means to take the work to the worker, instead of the worker to the workplace. Pérez, Sánchez, and Carnicer (2007) consider telework as an alternative form of work organization, characterized by allowing workers to use information and telecommunications totally or partially from their home or remote place. Boonen (2008) defines telework as a decentralized form of work that was born as a response of the West to the global economic crisis. Finally, Sakuda and Vasconcelos (2005) proposed another definition, considering that teleworking is the use of computers and telecommunications to change the already consolidated work structure, involving several economic, social, organizational, environmental, and legal aspects.

For this study, telework is any work carried out at a distance, that is, outside the workplace, using ICTs that allow working from anywhere, receiving and transmitting information, images or sound related to the work activity (SOBRATT, 2016). 


\section{Telework in the world}

From the study of Dunleavy, Margetts, Bastow et al. (2006), a series of discussions on the role of governance in the digital age pointed to the flexibility of work in public organizations. Among the issues pointed out, one of the organizational innovations that has been adopted in public organizations is teleworking. The issue has been approached recently by authors such as Dahlstrom (2013), Caillier (2012, 2013), Eom, Choi and Sung (2016) and De Vries, Tummers and Bekkers (2017, 2018).

There are several studies worldwide related to teleworking. According to Nilles (1994), telework includes more than just working at home and communicating with the office via telecommunication tools. It also includes working in work centers (an office area for employees from several companies) in the teleworkers neighborhood or in satellite offices (office of the company located in an area where there is a concentrated number of its teleworkers).

In this context of widespread use of telecommunications, it is important to initially understand the adaptation of users and the background of the implementation of this type of work. For example, Eom, Choi and Sung (2016) investigated the characteristics and behavior of South Korean government ICT users and analyzed the influence of the antecedents in the intention to use them. The study found that young people and employees in lower positions are more inclined to use government ICT and that social isolation and lack of communication, leadership and management influence negatively. Pérez, Sánchez and Carnicer (2007) studied the benefits and barriers of telework for employees and employers in industrial and service companies in Spain, identifying that the companies that adopted telework training programs faced fewer barriers.

Regarding the benefits for the worker, Tremblay (2002) carried out research in Quebec (Canada) with public and private companies to observe the advantages and disadvantages of telework perceived by workers in the region. The author found that there are significant gender differences in the workers' perception, although men and women agree that flexibility in working hours and not spending time in traffic are the main advantages of this form of work. Troup and Rose (2012) conducted comparative research between formal and informal telework in the public sector in Queensland (Australia) and found differences in job satisfaction and the distribution of tasks between men and women with children, suggesting that teleworking can affect work and family relationships.

Some research, however, pointed to the negative aspects of using telework. Cooper and Kurland (2002), in a comparative study of the impact of telework on the professional isolation of employees of public and private organizations, concluded that isolation is closely linked to the activities carried out. Also, Hislop, Axtell, Collins et al. (2015) studied how the use of ICTs (cell phones) for autonomous workers influence work experience. The authors focused on the worker's location, how they are managed and the experiences of social and professional isolation. The result showed that cell phone use provided greater spacetime flexibility and helped people cope with social isolation, but it made them feel that they were always available for work.

\section{Telework in Brazil}

In Brazil, recent studies on teleworking in the private sector show a tendency for companies to incorporate this new form of work. Mello, Santos, Shoiti et al. (2014) demonstrated that teleworking aims to reduce costs, improve productivity and quality of life of teleworkers by eliminating commuting time, as well as being used, from the point of view of social responsibility, for the social and digital inclusion of people with disabilities.

According to Gaspar, Bellini, Donaire et al. (2014), in a study with knowledge teleworkers, some of the elements that increase the chances of success in the adoption of this form of work are: the incentive for spontaneous telework, the previous analysis of the environment in which it will be developed, the teleworker's lifestyle, their training, social activities promoted, the stimulation of creativity, proactivity and innovation, as well as the gradual implementation.

Regarding the advantages and disadvantages of teleworking, the case study by Barros and Silva (2010) explored the individuals' perceptions about the elements of telework in the company Shell Brazil, contributing to identifying potential difficulties experienced by the employees (Box 1). Nohara, Acevedo, Ribeiro et al. (2010) addressed the perceptions of teleworkers regarding the quality of their professional life. The authors found that the main positive aspects of telework are autonomy, working time flexibility, family life and stress reduction. 
However, there are still challenges for the implementation of telework, such as difficulties with performance assessment and control of goals and results, as well as the definition of the teleworker's profile since not all employees have a compatible profile for this form of work (NOGUEIRA and PATINI, 2012).

Costa (2013), in a study with teleworkers from the private sector, discusses not only the concern over good management but also the construction of these employees as citizens and the freedom limitation observed as a consequence of telework. In research on teleworking's discourse and practice, Costa (2007) points out the existence of an optimistic and entrepreneurial discourse. In practice, however, the telework constitutes an invasion of the family environment and the transfer of business costs to the employee. Soares (1995) presents the lack of communication and socialization as disadvantages of telework.

More recently, Aderaldo, Aderaldo and Lima (2017) reinforce the pleasure-suffering dichotomy in telework; on the one hand, it can bring professional maturity to young people and on the other hand can lead to precariousness and lack of control of the workload.

\section{Telework in public administration}

Considering the high level of use of information and communication technologies in its activities, the Brazilian state is mature to discuss and approve norms to promote the introduction of teleworking in the public administration (SILVA, 2015). In the Brazilian public sector, Serpro was a pioneer in adopting teleworking in a comprehensive and structured way with a pilot project in 2005 (VILLARINHO and PASCHOAL, 2016).

As for the legislation, despite the pilot project started in 2005, an amendment to the Consolidation of Labor Laws (CLT) by Law 12551 only in 2011 guaranteed the same rights for teleworkers and traditional employees. The law states that teleworking requires practice, a physical structure and a different attitude from the people involved. However, it does not specify, for example, how to evaluate the worker's attendance, which is an indicator required in the employees' annual performance evaluation. Thus, the issue of telework legislation in Brazil remains embryonic and the legal framework must be developed to provide more security for all parts involved.

Box 1

Advantages and disadvantages of telework for employer and employee

\begin{tabular}{|c|l|l|}
\hline Authors & \multicolumn{1}{|c|}{ Advantages } & \multicolumn{1}{c|}{ Disadvantages } \\
\hline $\begin{array}{c}\text { Soares (1995); } \\
\text { Tremblay (2002) }\end{array}$ & $\begin{array}{l}\text { Flexible hours; Improvement in productivity } \\
\text { and work quality; Possibility to work close to } \\
\text { the family; and Less time wasted in commuting. }\end{array}$ & $\begin{array}{l}\text { Conflict between work and family life; } \\
\text { Low development and motivation; Lack } \\
\text { of specific training; Social isolation; Failing } \\
\text { technology, more work. }\end{array}$ \\
\hline $\begin{array}{c}\text { Pérez, Sanchez and } \\
\text { Carnicer (2007) }\end{array}$ & $\begin{array}{l}\text { Freedom to organize tasks; reduce costs and } \\
\text { space; self-employed; flexible hours and } \\
\text { work relations; managed per goals; freedom; } \\
\text { better productivity and quality of work; less } \\
\text { absenteeism; and opportunities for people } \\
\text { with disabilities. }\end{array}$ & $\begin{array}{l}\text { Equipment costs; difficulty for development, } \\
\text { motivation and organization; errors in } \\
\text { selecting tasks; professional isolation; } \\
\text { structural changes; perception of loss of } \\
\text { status; and psychological issues. }\end{array}$ \\
\hline Freitas (2008) & $\begin{array}{l}\text { Concentration; meals at home; flexible hours; } \\
\text { more time with family; fewer interruptions; } \\
\text { privacy; reduction in costs to the agency and } \\
\text { employee; less commuting; safety and silence. }\end{array}$ & $\begin{array}{l}\text { Higher water and electricity costs; } \\
\text { difficulties for control; distracted by } \\
\text { chores; lack of infrastructure; professional } \\
\text { and social isolation; and fear of poor } \\
\text { assessment. }\end{array}$ \\
\hline Barros and Silva (2010) & $\begin{array}{l}\text { Flexible hours; better productivity; less exposure } \\
\text { to violence/stress when commuting; safety } \\
\text { and silence. }\end{array}$ & $\begin{array}{l}\text { Conflict between work and family life; } \\
\text { lack of infrastructure and supervision; } \\
\text { professional isolation and oversight. }\end{array}$ \\
\hline Ribeiro et al. (2010) & $\begin{array}{l}\text { Freedom to organize tasks; more interaction } \\
\text { with family; better quality of life; less stress } \\
\text { commuting and reduction of commuting time. }\end{array}$ & $\begin{array}{l}\text { Conflict between work and family life; } \\
\text { difficulty to control; lack of recognition } \\
\text { from coworkers and supervisors; isolation; } \\
\text { more work. }\end{array}$ \\
\hline
\end{tabular}




\begin{tabular}{|c|c|c|}
\hline Authors & Advantages & Disadvantages \\
\hline Boscatte (2010) & $\begin{array}{l}\text { Better quality of life; better productivity; less } \\
\text { absenteeism and reduction of costs to the } \\
\text { employee. }\end{array}$ & \\
\hline $\begin{array}{c}\text { Gaspar, Bellini, } \\
\text { Donaire et al. (2014); } \\
\text { Nogueira and Patini (2012) }\end{array}$ & $\begin{array}{l}\text { Freedom to organize tasks; flexible hours; } \\
\text { more interaction with family; better planning } \\
\text { of activities; better quality and productivity at } \\
\text { work; less stress commuting and reduction of } \\
\text { costs to the employee. }\end{array}$ & $\begin{array}{l}\text { Difficulty to control and evaluate } \\
\text { performance; lack of infrastructure and } \\
\text { professional isolation. }\end{array}$ \\
\hline Costa (2013) & $\begin{array}{l}\text { Freedom to organize tasks and flexible hours; } \\
\text { balance between work and personal life; better } \\
\text { quality of life and reduced commuting time. }\end{array}$ & $\begin{array}{l}\text { Conflict between work and family } \\
\text { life; difficulty of development; lack of } \\
\text { supervision; social isolation; more } \\
\text { oversight; set up infrastructure at home. }\end{array}$ \\
\hline $\begin{array}{l}\text { Mello, Santos, Shoiti, } \\
\text { et al. (2014) }\end{array}$ & $\begin{array}{l}\text { Better quality of life; productivity and quality of } \\
\text { work; opportunities for people with disabilities } \\
\text { and cost reduction for the agency. }\end{array}$ & \\
\hline $\begin{array}{l}\text { Hislop, Axtell, Collins, } \\
\text { et al. (2015) }\end{array}$ & $\begin{array}{l}\text { Freedom to organize tasks; balance between } \\
\text { work and personal life and flexible hours. }\end{array}$ & Social isolation. \\
\hline Eom (2016) & $\begin{array}{l}\text { Work/home balance, better quality of life, } \\
\text { productivity, reduction of pollution and } \\
\text { commuting time. }\end{array}$ & $\begin{array}{l}\text { Professional and social isolation, unable } \\
\text { to adapt to teleworking. }\end{array}$ \\
\hline $\begin{array}{l}\text { Villarinho and Paschoal } \\
\qquad(2016)\end{array}$ & $\begin{array}{l}\text { Better quality of life, productivity, fewer } \\
\text { interruptions, stress and commuting time. }\end{array}$ & Social isolation and technology issues. \\
\hline $\begin{array}{l}\text { Aderaldo, Aderaldo } \\
\text { and Lima (2017) }\end{array}$ & Professional maturity of young employees. & $\begin{array}{l}\text { Precariousness and lack of control of } \\
\text { workload. }\end{array}$ \\
\hline
\end{tabular}

Source: Elaborated by the authors.

In this context, public organizations have established internal norms for teleworking, for example, the Ordinances 139/2009 and 99/2010 of Federal Court of Accounts, which regulated work carried out outside its premises.

Likewise, other public agencies have proposed the implementation of teleworking, Federal Revenue (2012), Attorney General - AGU (2011), Superior Labor Court - TST (2012) and Court of Justice of the State of Rio de Janeiro - TJRJ (2016).

Box 1 summarizes the literature reviewed in this study.

\section{METHODOLOGY}

The objective of this study is to deepen the analysis of telework in the Brazilian public administration. Among the motivations to choose this topic are the expansion of telework in Brazil in the last decades and the research gap represented by the small number of studies on telework in public administration.

The research adopted a mixed qualitative and quantitative methodology, adequate for dealing with complex social phenomena. The quantitative approach brings data and indicators representative of the available data. The qualitative approach complements the findings, deepening the information to explain social reality (CRESWELL and CLARK, 2017). 


\section{SELECTION OF CASES}

The selection of the public agencies participating in the research was based on a list published by Sobratt (2016) of the agencies that have used telework for at least two years. To expand the representativeness of the research, public agencies from all regions of the country were selected and contacted: Data Processing Service (Serpro), headquartered in Brasília with offices in 11 Brazilian state capitals; the Federal Court of Accounts (TCU), in the Federal District; the Regional Labor Court of the State of Paraíba (TRT-PB); the Court of Justice of the State of São Paulo (TJ-SP) and the Federal Revenue Department, with offices in Brasília and Rio de Janeiro. All the selected agencies required a formal request to participate in the research. However, only Serpro and the Federal Revenue Department effectively joined, responding to the questionnaires and participating in the interviews.

Serpro is a public company created by Law 4516/1964, which offers technology solutions. It has offices in all five regions of the country. Currently, it has about 10,000 employees, according to its management report (SERPRO, 2017). Its experience with teleworking started with a pilot project in 2005, with 18 people and then expanded to 87 in telework.

The Federal Revenue Department is an agency created by Decree 63659/1968 that seeks to carry out inspection procedures, i.e., activities that are conceptually external to the institution. In 2012, the pilot project for teleworking was regulated through RFB Ordinance $947 / 2012$, expanding this form of work to the areas of corporate systems development and analysis and judgment of fiscal, administrative processes, in which there are teleworkers in Brasilia and the Rio de Janeiro. It has about 23,000 employees and has about 120 teleworkers (RECEITA FEDERAL, 2017).

Box 2

Classification of advantages and disadvantages in indicators

\begin{tabular}{|c|c|c|c|c|c|}
\hline 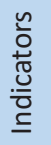 & Structural indicators & $\begin{array}{c}\text { Physical indicators / } \\
\text { well-being }\end{array}$ & Personal indicators & $\begin{array}{l}\text { Professional } \\
\text { indicators }\end{array}$ & $\begin{array}{l}\text { Psychological } \\
\text { indicators }\end{array}$ \\
\hline 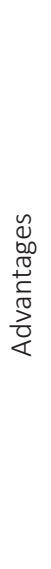 & $\begin{array}{l}\text { 1. Less costs for the company } \\
\text { 2. Less costs for the } \\
\text { employee }\end{array}$ & $\begin{array}{l}\text { 3. Less exposal to } \\
\text { violence } \\
\text { 4. Employment } \\
\text { opportunity } \\
\text { for people with } \\
\text { disabilities } \\
\text { 5. Less pollution } \\
\text { 6. Safety }\end{array}$ & $\begin{array}{l}\text { 7. Self-employment } \\
\text { 8. Meals at home } \\
\text { 9. Time flexibility } \\
\text { 10. Better quality of life } \\
\text { 11. Less interruption } \\
\text { 12. Privacy } \\
\text { 13. Less time } \\
\text { commuting } \\
\text { 14. Silence }\end{array}$ & $\begin{array}{l}\text { 15. Freedom to } \\
\text { organize tasks } \\
\text { 16. Flexibility } \\
\text { in working } \\
\text { relationships } \\
\text { 17. Goal-oriented } \\
\text { management } \\
\text { 18. Better } \\
\text { productivity at work } \\
\text { 19. Better quality } \\
\text { of work } \\
\text { 20. Less } \\
\text { absenteeism }\end{array}$ & $\begin{array}{l}\text { 21. Concentration } \\
\text { 22. Balance } \\
\text { between work and } \\
\text { personal life } \\
\text { 23. More } \\
\text { interaction with } \\
\text { the family } \\
\text { 24. Less stress in } \\
\text { commuting }\end{array}$ \\
\hline
\end{tabular}




\begin{tabular}{|c|c|c|c|c|c|}
\hline 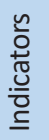 & Structural indicators & $\begin{array}{c}\text { Physical indicators / } \\
\text { well-being }\end{array}$ & Personal indicators & $\begin{array}{l}\text { Professional } \\
\text { indicators }\end{array}$ & $\begin{array}{l}\text { Psychological } \\
\text { indicators }\end{array}$ \\
\hline 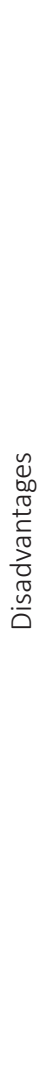 & $\begin{array}{l}\text { 1. Increasing costs of } \\
\text { electricity and water supply } \\
\text { 2. Costs with equipment } \\
\text { 3. Organizational difficulties } \\
\text { 4. Lack of infrastructure } \\
\text { 5. Lack of specific training for } \\
\text { telework } \\
\text { 6. Build structure at home } \\
\text { 7. Changes in organizational } \\
\text { structure } \\
\text { 8. Technology still does not } \\
\text { perform as expected }\end{array}$ & & $\begin{array}{l}\text { 9. Distraction with } \\
\text { domestic chores }\end{array}$ & $\begin{array}{l}\text { 10. Professional } \\
\text { development in the } \\
\text { agency } \\
\text { 11. Difficulty of } \\
\text { control } \\
\text { 12. Difficulty of } \\
\text { development } \\
\text { 13. Difficulty of } \\
\text { motivation } \\
\text { 14. Errors in } \\
\text { selecting the task } \\
\text { 15. Lack of } \\
\text { recognition from } \\
\text { coworkers } \\
\text { 16. Lack of } \\
\text { supervision } \\
\text { 17. Professional } \\
\text { isolation } \\
\text { 18. More oversight } \\
\text { 19. Lack of } \\
\text { adaptation to } \\
\text { telework } \\
\text { 20. Perception of } \\
\text { loss of status } \\
21 \text {. Fear of poor } \\
\text { assessment }\end{array}$ & $\begin{array}{l}\text { 22. Conflict } \\
\text { between work and } \\
\text { family life } \\
\text { 23. Social isolation } \\
\text { 24. Psychological } \\
\text { problems }\end{array}$ \\
\hline
\end{tabular}

Source: Elaborated by the authors.

\section{Universe and sample}

From a universe of about 210 teleworkers, 98 questionnaires were answered: 70 from Serpro and 28 from the Federal Revenue Department. Managers answered 28 questionnaires, 25 from Serpro and three from the Federal Revenue Department. Four interviews were conducted with managers who provided e-mail and telephone contact information in the third section of the questionnaire, three interviews with managers working in Serpro and one in the Federal Revenue Service.

Box 3 presents an overview of the profile of the 28 managers who responded to the questionnaire. Among the respondents, there were twenty-two male and six female. Most managers (39\%) were between 50 and 59 years old, followed by those who were between 35 and 39 years old (28\%). As for education, $93 \%$ had at least higher education, which suggests that managers are more experienced and educated.

Box 3

Managers' profile

\begin{tabular}{|c|c|c|c|c|c|c|}
\hline Manager & Agency & Sex & Age & Education & $\begin{array}{c}\text { Length of time in the agency } \\
\text { (years) }\end{array}$ & $\begin{array}{c}\text { Length of time as telework } \\
\text { manager (years) }\end{array}$ \\
\hline M1 & SERPRO & Female & 50 to 59 & Masters & 10 or more & Maximum 2 \\
\hline M2 & SERPRO & Male & 50 to 59 & Degree & 10 or more & Maximum 2 \\
\hline M3 & SERPRO & Male & 60 or more & Degree & 10 or more & More than 10 \\
\hline M4 & SERPRO & Female & 60 or more & Post-Degree & 10 or more & Maximum 2 \\
\hline
\end{tabular}


Continue

\begin{tabular}{|c|c|c|c|c|c|c|}
\hline Manager & Agency & Sex & Age & Education & $\begin{array}{l}\text { Length of time in the agency } \\
\text { (years) }\end{array}$ & $\begin{array}{l}\text { Length of time as telework } \\
\text { manager (years) }\end{array}$ \\
\hline M5 & SERPRO & Male & 50 to 59 & Post-Degree & 10 or more & More than 2 and less than 5 \\
\hline M6 & SERPRO & Male & 35 to 39 & Post-Degree & 10 or more & More than 2 and less than 5 \\
\hline M7 & SERPRO & Female & 50 to 59 & High-School & 10 or more & More than 2 and less than 5 \\
\hline M8 & SERPRO & Female & 35 to 39 & Post-Degree & More than 5 and less than 10 & Maximum 2 \\
\hline M9 & SERPRO & Male & 50 to 59 & Post-Degree & 10 or more & More than 2 and less than 5 \\
\hline M10 & SERPRO & Male & 35 to 39 & Post-Degree & More than 5 and less than 10 & Maximum 2 \\
\hline M11 & SERPRO & Male & 50 to 59 & Post-Degree & 10 or more & More than 2 and less than 5 \\
\hline M12 & SERPRO & Male & 50 to 59 & Degree & 10 or more & More than 2 and less than 5 \\
\hline M13 & SERPRO & Female & 35 to 39 & Post-Degree & 10 or more & More than 2 and less than 5 \\
\hline M14 & SERPRO & Male & 50 to 59 & Post-Degree & 10 or more & More than 5 and less than 10 \\
\hline M15 & SERPRO & Male & 45 to 49 & Post-Degree & 10 or more & More than 5 and less than 10 \\
\hline M16 & SERPRO & Male & 45 to 49 & Post-Degree & 10 or more & More than 10 \\
\hline M17 & SERPRO & Male & 40 to 44 & Degree & More than 5 and less than 10 & More than 2 and less than 5 \\
\hline M18 & SERPRO & Male & 40 to 44 & Masters & 10 or more & More than 2 and less than 5 \\
\hline M19 & SERPRO & Male & 50 to 59 & Post-Degree & 10 or more & More than 2 and less than 5 \\
\hline $\mathrm{M} 20$ & SERPRO & Male & 45 to 49 & High-School & 10 or more & More than 10 \\
\hline M21 & SERPRO & Male & 50 to 59 & Post-Degree & 10 or more & Maximum 2 \\
\hline M22 & SERPRO & Male & 35 to 39 & Masters & 10 or more & More than 2 and less than 5 \\
\hline $\mathrm{M} 23$ & SERPRO & Male & 30 to 34 & Post-Degree & More than 2 and less than 5 & Maximum 2 \\
\hline $\mathrm{M} 24$ & SERPRO & Male & 60 or more & Degree & 10 or more & Maximum 2 \\
\hline M25 & SERPRO & Male & 50 to 59 & Post-Degree & 10 or more & More than 2 and less than 5 \\
\hline M26 & $\begin{array}{l}\text { FEDERAL } \\
\text { REVENUE }\end{array}$ & Male & 35 to 39 & Post-Degree & More than 2 and less than 5 & More than 2 and less than 5 \\
\hline M27 & $\begin{array}{l}\text { FEDERAL } \\
\text { REVENUE }\end{array}$ & Female & 35 to 39 & Post-Degree & More than 2 and less than 5 & More than 2 and less than 5 \\
\hline M28 & $\begin{array}{l}\text { FEDERAL } \\
\text { REVENUE }\end{array}$ & Male & 35 to 39 & Masters & 10 or more & More than 2 and less than 5 \\
\hline
\end{tabular}

Source: Elaborated by the authors.

\section{Data collection instruments}

From the advantages and disadvantages presented in Box 2, questionnaires were elaborated for the two groups (teleworkers and managers), to obtain a broader perception of the aspects related to telework in the agencies. A pilot test was carried out to validate the questionnaire with two professionals working at Serpro, who suggested changes that were incorporated.

After adjustments, the questionnaires were made available in a digital format and organized in three sections. The first section was designed to identify the profile of the interviewee: agency, gender, age, education, length of work in the agency as manager or teleworker and length of work in the agency as a traditional employee. The second section has included statements about costs for teleworker and manager, infrastructure and teleworking environment, exposure to violence and pollution, working relationship with manager and colleagues, productivity, flexibility, professional development in the agency, social and professional isolation, control and teleworker management and adaptation to telework. Finally, the third section left some space where respondents offered other information about their daily work related to teleworking. The managers were requested to provide their email and telephone to schedule interviews. 
Of the 24 advantages and 24 disadvantages identified (Box 2), 40 statements were presented to teleworkers. The other eight were evaluated only by the managers: 'costs with equipment,' 'organizational difficulties,' 'employment opportunities for people with disabilities,' 'difficulty of control,' 'errors of selecting the task,' 'lack of supervision,' 'professional isolation,' and 'psychological problems'. The advantage 'balance between work and personal life,' was assessed in a complementary way to the disadvantage 'conflict between work and family life.' Managers evaluated the eight statements mentioned and another twelve that were evaluated by teleworkers, totaling 20 statements with emphasis on the structural and professional indicators.

For the teleworkers, there were eight statements related to structural indicators, three to physical indicators/well-being, nine to personal indicators, fifteen to professional indicators and five to psychological indicators, totaling 40 statements. For the managers, there were six statements related to structural indicators, one to physical indicators/wellness, twelve to professional indicators and one to psychological indicators, totaling 20 statements evaluated. As the data collection stage obtained 98 responses from teleworkers (which is enough for a more advanced study), we conducted a factor analysis (principal component analysis), as well as applying descriptive statistics.

The second part of the research contained interviews with the managers, conducted based on a semi-structured script that explored their perceptions according to the following categories: a) implementation of telework in the public agency; b) telework selection process; c) advantages and disadvantages of teleworking for the manager and the teleworker; d) advantages and disadvantages of teleworking for the public agency; e) supervision of teleworkers; and f) workers performance evaluation system.

\section{RESULTS AND ANALYSIS}

\section{Descriptive statistics}

The descriptive statistics enabled quantitative analysis of the data. The profile of the participants that completed the questionnaire was verified to provide an overview of the 98 teleworkers, as well as to observe the responses proposed in the questionnaire regarding the advantages and disadvantages of teleworking in public administration.

It was found that of the 98 participating teleworkers, 58 were male and 40 female, $41 \%$ aged between 50 and 59 years old, $40 \%$ aged between 45 and 49,13\% aged between 40 and 44 years old, 13\% between 35 and 39, 12\% over 60 years old and $6 \%$ aged between 30 and 34 years old. The data suggest that the maturity of the employees marks the teleworkers profile, as well as their experience, considering that $68 \%$ of the teleworkers had worked for 10 years or more at the agency. Therefore, it is fair to say that there were fewer opportunities for younger employees. As for education, 17 teleworkers (17.4\%) completed high school and 81 (82.6\%) completed at least a degree, showing that higher education seems to be a requirement to be a teleworker in the public agencies studied.

Table 1 shows the percentages of disagreement/agreement regarding the statements of teleworkers of the indicators in Box 2. For analysis, in some cases the results of the "partially agree" and "completely agree" as well as "partially disagree" and "completely disagree" were summed.

Table 1

Evaluation of teleworkers regarding the advantages and disadvantages of teleworking

\begin{tabular}{c|c|c|c|c|c|c}
\hline $\begin{array}{c}\text { Statements } \\
\text { for teleworkers }\end{array}$ & $\begin{array}{c}\text { Completely } \\
\text { disagree }\end{array}$ & $\begin{array}{c}\text { Partially } \\
\text { disagree }\end{array}$ & $\begin{array}{c}\text { Neither agree } \\
\text { nor disagree }\end{array}$ & $\begin{array}{c}\text { Partially } \\
\text { agree }\end{array}$ & $\begin{array}{c}\text { Completely } \\
\text { agree }\end{array}$ & N/A \\
\hline $\begin{array}{c}\text { There was an increase in my costs for } \\
\text { water and electricity }\end{array}$ & $30.6 \%$ & $11.2 \%$ & $9.2 \%$ & $21.4 \%$ & $20.4 \%$ & $7.1 \%$ \\
\hline My cost for transportation reduced & $1.0 \%$ & $1.0 \%$ & $0.0 \%$ & $8.2 \%$ & $83.7 \%$ & $6.1 \%$ \\
\hline $\begin{array}{c}\text { I did not have the necessary infrastructure } \\
\text { for teleworking }\end{array}$ & $67.3 \%$ & $14.3 \%$ & $4.1 \%$ & $8.2 \%$ & $1.0 \%$ & $5.1 \%$ \\
\hline I had specific training to start teleworking & $21.4 \%$ & $12.2 \%$ & $6.1 \%$ & $17.3 \%$ & $32.7 \%$ & $10.2 \%$ \\
\hline
\end{tabular}




\begin{tabular}{|c|c|c|c|c|c|c|}
\hline $\begin{array}{l}\text { Statements } \\
\text { for teleworkers }\end{array}$ & $\begin{array}{l}\text { Completely } \\
\text { disagree }\end{array}$ & $\begin{array}{l}\text { Partially } \\
\text { disagree }\end{array}$ & $\begin{array}{l}\text { Neither agree } \\
\text { nor disagree }\end{array}$ & $\begin{array}{l}\text { Partially } \\
\text { agree }\end{array}$ & $\begin{array}{l}\text { Completely } \\
\text { agree }\end{array}$ & N/A \\
\hline I set up my own infrastructure at home & $7.1 \%$ & $7.1 \%$ & $5.1 \%$ & $22.4 \%$ & $53.1 \%$ & $5.1 \%$ \\
\hline $\begin{array}{l}\text { There were changes in the agency`s } \\
\text { organizational structure }\end{array}$ & $43.9 \%$ & $7.1 \%$ & $12.2 \%$ & $8.2 \%$ & $8.2 \%$ & $20.4 \%$ \\
\hline My costs were reduced & $4.1 \%$ & $3.1 \%$ & $3.1 \%$ & $21.4 \%$ & $63.3 \%$ & $5.1 \%$ \\
\hline The available technology is adequate & $1.0 \%$ & $7.1 \%$ & $1.0 \%$ & $20.4 \%$ & $65.3 \%$ & $5.1 \%$ \\
\hline I am less exposed to violence & $1.0 \%$ & $0.0 \%$ & $0.0 \%$ & $7.1 \%$ & $87.8 \%$ & $4.1 \%$ \\
\hline I am less exposed to pollution & $1.0 \%$ & $0.0 \%$ & $3.1 \%$ & $4.1 \%$ & $87.8 \%$ & $4.1 \%$ \\
\hline I feel safer working from home & $1.0 \%$ & $0.0 \%$ & $1.0 \%$ & $8.2 \%$ & $85.7 \%$ & $4.1 \%$ \\
\hline Domestic chores are source of distraction & $44.9 \%$ & $17.3 \%$ & $8.2 \%$ & $12.2 \%$ & $9.2 \%$ & $8.2 \%$ \\
\hline I can do other jobs independently & $30.6 \%$ & $6.1 \%$ & $13.3 \%$ & $12.2 \%$ & $13.3 \%$ & $24.5 \%$ \\
\hline I like to have my meals at home & $3.1 \%$ & $0.0 \%$ & $5.1 \%$ & $9.2 \%$ & $76.5 \%$ & $6.1 \%$ \\
\hline Time flexibility is a benefit & $4.1 \%$ & $1.0 \%$ & $3.1 \%$ & $2.0 \%$ & $84.7 \%$ & $5.1 \%$ \\
\hline My quality of life improved & $1.0 \%$ & $0.0 \%$ & $0.0 \%$ & $4.1 \%$ & $90.8 \%$ & $4.1 \%$ \\
\hline I have less distruptions when I work & $1.0 \%$ & $2.0 \%$ & $4.1 \%$ & $16.3 \%$ & $71.4 \%$ & $5.1 \%$ \\
\hline I have more privacy & $1.0 \%$ & $1.0 \%$ & $0.0 \%$ & $12.2 \%$ & $81.6 \%$ & $4.1 \%$ \\
\hline $\begin{array}{l}\text { The reduction in commuting } \\
\text { time is a benefit }\end{array}$ & $1.0 \%$ & $0.0 \%$ & $0.0 \%$ & $1.0 \%$ & $93.9 \%$ & $4.1 \%$ \\
\hline My work environment is quiet & $2.0 \%$ & $1.0 \%$ & $0.0 \%$ & $10.2 \%$ & $82.7 \%$ & $4.1 \%$ \\
\hline I am free to organize my tasks & $1.0 \%$ & $0.0 \%$ & $1.0 \%$ & $19.4 \%$ & $74.5 \%$ & $4.1 \%$ \\
\hline $\begin{array}{l}\text { Promotion in the agency } \\
\text { has become difficult }\end{array}$ & $41.8 \%$ & $9.2 \%$ & $17.3 \%$ & $17.3 \%$ & $6.1 \%$ & $8.2 \%$ \\
\hline $\begin{array}{l}\text { My development within the } \\
\text { agency is hindered }\end{array}$ & $58.2 \%$ & $11.2 \%$ & $8.2 \%$ & $13.3 \%$ & $1.0 \%$ & $8.2 \%$ \\
\hline I feel motivated with the telework & $2.0 \%$ & $0.0 \%$ & $1.0 \%$ & $14.3 \%$ & $77.6 \%$ & $5.1 \%$ \\
\hline $\begin{array}{c}\text { My manager gives me tasks I am } \\
\text { not able to carry out }\end{array}$ & $72.4 \%$ & $11.2 \%$ & $3.1 \%$ & $3.1 \%$ & $1.0 \%$ & $9.2 \%$ \\
\hline $\begin{array}{l}\text { I do not have recognition } \\
\text { from my coworkers }\end{array}$ & $64.3 \%$ & $7.1 \%$ & $9.2 \%$ & $8.2 \%$ & $4.1 \%$ & $7.1 \%$ \\
\hline I have more felixibility in work relations & $2.0 \%$ & $2.0 \%$ & $17.3 \%$ & $33.7 \%$ & $40.8 \%$ & $4.1 \%$ \\
\hline My work is managed by goals & $6.1 \%$ & $8.2 \%$ & $7.1 \%$ & $19.4 \%$ & $45.9 \%$ & $13.3 \%$ \\
\hline $\begin{array}{l}\text { The oversight on the results is more } \\
\text { accentuated for teleworkers }\end{array}$ & $42.9 \%$ & $6.1 \%$ & $16.3 \%$ & $13.3 \%$ & $13.3 \%$ & $8.2 \%$ \\
\hline My productivity at work increased & $2.0 \%$ & $1.0 \%$ & $7.1 \%$ & $14.3 \%$ & $71.4 \%$ & $4.1 \%$ \\
\hline The quality of my work improved & $1.0 \%$ & $0.0 \%$ & $7.1 \%$ & $17.3 \%$ & $70.4 \%$ & $4.1 \%$ \\
\hline
\end{tabular}




\begin{tabular}{c|c|c|c|c|c|c}
\hline $\begin{array}{c}\text { Statements } \\
\text { for teleworkers }\end{array}$ & $\begin{array}{c}\text { Completely } \\
\text { disagree }\end{array}$ & $\begin{array}{c}\text { Partially } \\
\text { disagree }\end{array}$ & $\begin{array}{c}\text { Neither agree } \\
\text { nor disagree }\end{array}$ & $\begin{array}{c}\text { Partially } \\
\text { agree }\end{array}$ & $\begin{array}{c}\text { Completely } \\
\text { agree }\end{array}$ & N/A \\
\hline I did not adapt to telework & $86.7 \%$ & $2.0 \%$ & $2.0 \%$ & $0.0 \%$ & $3.1 \%$ & $6.1 \%$ \\
\hline $\begin{array}{c}\text { I feel that I lost status } \\
\text { because of the telework }\end{array}$ & $65.3 \%$ & $7.1 \%$ & $6.1 \%$ & $11.2 \%$ & $4.1 \%$ & $6.1 \%$ \\
\hline I fear poor assessment & $67.3 \%$ & $6.1 \%$ & $6.1 \%$ & $11.2 \%$ & $3.1 \%$ & $6.1 \%$ \\
\hline I do not miss work as often & $11.2 \% \%$ & $1.0 \%$ & $3.1 \%$ & $3.1 \%$ & $65.3 \%$ & $16.3 \%$ \\
\hline I have difficulties to focus at home & $82.7 \%$ & $8.2 \%$ & $0.0 \%$ & $1.0 \%$ & $1.0 \%$ & $7.1 \%$ \\
\hline $\begin{array}{c}\text { There is conflict between } \\
\text { work and family life }\end{array}$ & $79.6 \%$ & $6.1 \%$ & $3.1 \%$ & $4.1 \%$ & $1.0 \%$ & $6.1 \%$ \\
\hline My social life is hindered & $83.7 \%$ & $2.0 \%$ & $2.0 \%$ & $5.1 \%$ & $1.0 \%$ & $6.1 \%$ \\
\hline I have more interaction with my family & $2.0 \%$ & $0.0 \%$ & $5.1 \%$ & $19.4 \%$ & $67.3 \%$ & $6.1 \%$ \\
\hline I have less stress with commuting & $3.1 \%$ & $1.0 \%$ & $1.0 \%$ & $4.1 \%$ & $85.7 \%$ & $5.1 \%$ \\
\hline
\end{tabular}

Source: Elaborated by the authors.

$\mathrm{N} / \mathrm{A}=$ None of the alternatives.

Therefore, on the structural indicators, the analysis reveals that, for cost reduction, teleworkers were divided $(41.8 \%$ agreed that there was a reduction in the cost of water and electricity), but the same percentage disagrees with this reduction. The most notable gain in the respondents' perception was the reduction of transportation costs with the agreement of $91.9 \%$.

Regarding infrastructure, $81.6 \%$ said that they disagree that there is a lack of structure for teleworking. However, in the item related to specific training, even though $50 \%$ agreed indicating that there was training for teleworking, there was the disagreement of $33.6 \%$ of the respondents, which reveals a point for attention since the training can help to reduce the insecurity generated by the new forms of work adopted. Regarding the available technology, $85.7 \%$ considered it adequate.

Concerning physical and welfare indicators, teleworkers largely agreed they feel safer working at home (85.7\%) and less exposed to violence and pollution, both with $87.8 \%$. The analysis of personal indicators revealed that, although $62.2 \%$ disagreed, $21.4 \%$ agreed that domestic activities were a source of distraction in teleworking, which may contribute to a decline in professional performance. The topic of distraction is reinforced when $25.5 \%$ of teleworkers agreed that they could do other jobs at the same time, independently, with $24.5 \%$ preferring not to respond, which indicates that the number may be even higher, revealing distortion of the objectives of teleworking.

Other aspects of the personal indicators were flexible hours, less commuting, fewer interruptions, more privacy, meals at home, better quality of life, and silence in the work environment had high agreement rates, between 80 and $95 \%$, appearing as the main block of benefits perceived by teleworkers.

Regarding the professional indicators, the aspects of freedom, motivation, flexibility, productivity, and quality of work appeared with a high level of agreement, between 74 and $94 \%$, showing that teleworkers considered these elements as benefits. However, for the promotion and professional development in the agency, it is important to observe the $23.4 \%$ and $14.3 \%$ of the respondents, respectively, that agreed that promotion and professional development became more challenging after teleworking. Also, $12.3 \%$ agreed that they do not obtain recognition from coworkers, $26.6 \%$ considered that there is more oversight regarding results for teleworkers, $15.3 \%$ perceived that they had lost their status after teleworking and $14.3 \%$ feared poor assessment. Although these were not high numbers, they were the type of findings that indicate the care needed to create mechanisms of isonomy and support for the teleworkers. 
Finally, the psychological indicators showed that the teleworkers operating in public agencies studied did not consider they have difficulties of concentration, prejudice for social life, nor a conflict between work and family life since the results of these aspects were above the $80 \%$ of disagreement with the statements. Also, they affirmed to have greater interaction with family and less stress, with agreement above $85 \%$. These results diverge in part from the findings of Soares (1995), who pointed out a possible re-adaptation of the professional to the context of labor in the new millennium. They also diverge from the results found by Rocha and Amador (2018), who emphasized risks of intensification of work, difficulty in separating space and length of time working, family and personal life, and the risk of extended working hours indefinitely due to the use of digital devices.

In a complementary way, Table 5 presents all the percentages of agreement/disagreement of the managers' affirmations in the research, and it is analyzed by the categories established in the item "data collection instruments."

Regarding the implementation of telework, although more than $70 \%$ of the managers mentioned that they observe a reduction in costs with space, and $46.1 \%$ stated that there was a reduction in costs, $28.6 \%$ reported difficulties to implement telework.

For $64.3 \%$ of the managers there was no change in the organizational structure, and for $82.1 \%$ the necessary infrastructure was made available. However, $25 \%$ believed that there was a lack of specific training to migrate to telework, which may have made the transition harder. Also, $28.6 \%$ pointed out that there were no people with disabilities in the teleworking program, compromising the aspect of inclusion in the selection of teleworkers.

Regarding the advantages and disadvantages, $85.7 \%$ of managers believed that teleworkers are free to organize tasks, $82.2 \%$ said that they feel motivated by teleworking, and $64.3 \%$ that they have flexibility in working relationships. On the other hand, $21.5 \%$ believed that professional development within the agency was hindered, and $14.1 \%$ believed that they were not recognized by co-workers.

Finally, regarding supervision and evaluation, $71.4 \%$ considered that teleworkers are managed by goals and $53.6 \%$ considered them to be more productive. However, $17.9 \%$ affirmed to have difficulties controlling and supervising the work, showing that some adjustments still need to be made so that these forms of work can be fully used in public agencies.

Table 2

Evaluation of managers about the advantages and disadvantages of teleworking

\begin{tabular}{l|c|c|c|c|c|c}
\hline \multicolumn{1}{c|}{ Statements for managers } & $\begin{array}{c}\text { Completely } \\
\text { disagree }\end{array}$ & $\begin{array}{c}\text { Partially } \\
\text { disagree }\end{array}$ & $\begin{array}{c}\text { Neither agree } \\
\text { nor disagree }\end{array}$ & $\begin{array}{c}\text { Partially } \\
\text { agree }\end{array}$ & $\begin{array}{c}\text { Completely } \\
\text { agree }\end{array}$ & N/A \\
\hline $\begin{array}{l}\text { My agency had problems } \\
\text { implementing teleworking }\end{array}$ & $42.9 \%$ & $14.3 \%$ & $3.6 \%$ & $25.0 \%$ & $3.6 \%$ & $10.7 \%$ \\
\hline My agency's costs were reduced & $3.6 \%$ & $0.0 \%$ & $32.1 \%$ & $14.3 \%$ & $32.1 \%$ & $17.9 \%$ \\
\hline My agency reduced costs with space & $7.1 \%$ & $0.0 \%$ & $10.7 \%$ & $35.7 \%$ & $35.7 \%$ & $10.7 \%$ \\
\hline $\begin{array}{l}\text { There were changes to organizational } \\
\text { structure of the agency }\end{array}$ & $60.7 \%$ & $3.6 \%$ & $7.1 \%$ & $3.6 \%$ & $0.0 \%$ & $25.0 \%$ \\
\hline $\begin{array}{l}\text { The necessary infrastructure } \\
\text { for telework is available }\end{array}$ & $0.0 \%$ & $0.0 \%$ & $3.6 \%$ & $21.4 \%$ & $60.7 \%$ & $14.3 \%$ \\
\hline $\begin{array}{l}\text { Specific training for teleworking is } \\
\text { available }\end{array}$ & $14.3 \%$ & $10.7 \%$ & $7.1 \%$ & $28.6 \%$ & $25.0 \%$ & $14.3 \%$ \\
\hline $\begin{array}{l}\text { There are people with } \\
\text { disabilities teleworking }\end{array}$ & $28.6 \%$ & $0.0 \%$ & $21.4 \%$ & $7.1 \%$ & $21.4 \%$ & $21.4 \%$ \\
\hline $\begin{array}{l}\text { Teleworkers are free to } \\
\text { organize their tasks }\end{array}$ & $3.6 \%$ & $0.0 \%$ & $0.0 \%$ & $35.7 \%$ & $50.0 \%$ & $10.7 \%$ \\
\hline $\begin{array}{l}\text { Promotion in the agency has become } \\
\text { difficult for them }\end{array}$ & $39.3 \%$ & $7.1 \%$ & $17.9 \%$ & $10.7 \%$ & $3.6 \%$ & $21.4 \%$ \\
\hline
\end{tabular}




\begin{tabular}{|c|c|c|c|c|c|c|}
\hline Statements for managers & $\begin{array}{l}\text { Completely } \\
\text { disagree }\end{array}$ & $\begin{array}{l}\text { Partially } \\
\text { disagree }\end{array}$ & $\begin{array}{l}\text { Neither agree } \\
\text { nor disagree }\end{array}$ & $\begin{array}{l}\text { Partially } \\
\text { agree }\end{array}$ & $\begin{array}{l}\text { Completely } \\
\text { agree }\end{array}$ & N/A \\
\hline It is hard to control their work & $46.4 \%$ & $21.4 \%$ & $3.6 \%$ & $17.9 \%$ & $0.0 \%$ & $10.7 \%$ \\
\hline $\begin{array}{l}\text { The teleworkers development } \\
\text { within the agency is hindered }\end{array}$ & $46.4 \%$ & $7.1 \%$ & $14.3 \%$ & $17.9 \%$ & $3.6 \%$ & $10.7 \%$ \\
\hline $\begin{array}{l}\text { Teleworkers are motivated by } \\
\text { telework }\end{array}$ & $0.0 \%$ & $3.6 \%$ & $0.0 \%$ & $17.9 \%$ & $64.3 \%$ & $14.3 \%$ \\
\hline $\begin{array}{l}\text { I have made mistakes in selecting } \\
\text { teleworkers' tasks }\end{array}$ & $42.9 \%$ & $21.4 \%$ & $10.7 \%$ & $7.1 \%$ & $0.0 \%$ & $17.9 \%$ \\
\hline Lack of recognition from coworkers & $50.0 \%$ & $25.0 \%$ & $0.0 \%$ & $10.7 \%$ & $3.6 \%$ & $10.7 \%$ \\
\hline I find it hard to supervise teleworkers & $53.6 \%$ & $14.3 \%$ & $3.6 \%$ & $14.3 \%$ & $3.6 \%$ & $10.7 \%$ \\
\hline $\begin{array}{l}\text { Teleworkers have flexibility } \\
\text { in work relations }\end{array}$ & $14.3 \%$ & $3.6 \%$ & $7.1 \%$ & $28.6 \%$ & $35.7 \%$ & $10.7 \%$ \\
\hline Teleworkers are managed by goals & $3.6 \%$ & $7.1 \%$ & $7.1 \%$ & $21.4 \%$ & $50.0 \%$ & $10.7 \%$ \\
\hline Teleworkers are more productive & $7.1 \%$ & $7.1 \%$ & $21.4 \%$ & $17.9 \%$ & $35.7 \%$ & $10.7 \%$ \\
\hline $\begin{array}{l}\text { Some people are not } \\
\text { suited to telework }\end{array}$ & $32.1 \%$ & $3.6 \%$ & $7.1 \%$ & $14.3 \%$ & $25.0 \%$ & $17.9 \%$ \\
\hline $\begin{array}{l}\text { There have been cases } \\
\text { of psychological issues }\end{array}$ & $42.9 \%$ & $3.6 \%$ & $17.9 \%$ & $7.1 \%$ & $0.0 \%$ & $28.6 \%$ \\
\hline
\end{tabular}

Source: Elaborated by the authors.

In addition to these results, $29.3 \%$ of the managers mentioned that some people did not adapt to telework, and $7.1 \%$ mentioned the existence of cases where psychological problems were identified, which is the aspect with the greatest lack of response (28.6\%). This situation revealed a concern about the teleworkers' physical and mental health, pointing to the need for careful selection of those who are fit and above all willing to work in this regime.

\section{Results of the factor analysis}

The research used the software SPSS Statistics to carry out the factor analysis with the answers obtained from the 40 affirmations made to teleworkers observing a Likert scale, aiming to verify whether the advantages and disadvantages identified in the literature review could be grouped in the form of Box 2. The scale adopted had the following values: Completely disagree (1), partially disagree (2), neither agree nor disagree (3), partially agree (4), completely agree (5).

The quantitative analysis of this study consisted of evaluating the questionnaire applied to the 98 teleworkers, grouping the statements regarding the advantages and disadvantages of telework in factors created by factor analysis. The objective of this procedure was to reduce the number of variables explaining the main advantages and disadvantages of teleworking for teleworkers of Serpro and the Federal Revenue Department, with the lowest possible loss of information.

The factor analysis package of SPSS Statistics software was used, identifying the following criteria: the anti-image correlation matrix, which brings the values related to the observed measure of sampling adequacy (MSA); factors commonalities; and factor loadings, that were higher than 1.0 .

The factor analysis by the principal component method evaluated the values of MSA and factor loading. For the sample of 40 variables, a Kaiser-Meyer-Olkin (KMO) adequacy measure of 0.751 was obtained, indicating the adequacy of the factor analysis. The Barlett sphericity test, used to examine the hypothesis that the variables were not correlated in the population, was adequate at the significance level of $1 \%$. This result generated twelve factors that corresponded to $73.84 \%$ of the data variance. 
The first factor is represented by 17 variables, which corresponded to $25.87 \%$ of the explained variance, and the second factor is represented by five variables, corresponding to $9.93 \%$. When comparing the results obtained by the factor analysis with the grouping shown in Box 2, we verified that five indicators listed could be more detailed in the factors found, in order to accurately capture the variations of the respondents' opinion. From the descriptive statistics presented, the factors can be analyzed as follows:

- Factor 1 - Quality of life at work: It was representative of all the indicators in Box 2, except for the psychological ones. A disadvantage indicator "technology still does not perform as expected" was not confirmed as a disadvantage in this study, i.e., for participants the available technology was adequate.

- Factor 2-Professional indicators of teleworking: The factor focused on the statements about the teleworker and their professional development in the agency. The indicators of disadvantages evidenced in the factor were not confirmed in this study, as the majority of the respondents did not consider their professional development as a problem.

- Factor 3 - Personal indicators of teleworking: It brought the facilities/difficulties between personal and professional life of the teleworker. The disadvantage indicator "Social isolation" was not confirmed as a disadvantage in this study.

- Factor 4-Structural indicators of teleworking: Represented the material and technical infrastructures of teleworking. The indicators of disadvantages evidenced in the factor were not confirmed since most of the respondents said that there was no lack of infrastructure nor an error in the selection of tasks.

- Factor 5 - Balance between work and family: the factor reflected the parsimony between better work attendance and more interaction with the family. The results validated these items as advantages of teleworking.

- Factor 6-Relationship with the manager: This factor brought two professional indicators of oversight and delivery of work. The disadvantage indicator "more oversight" was not confirmed as a disadvantage in this study, as most (43\%) affirmed that there was not more oversight for teleworkers in comparison to other workers, but the greater number of respondents from Serpro influenced this result. For the Federal Revenue Department, teleworkers have $15 \%$ higher performance targets than traditional workers. If the teleworker does not meet the performance goal, they can be requested to return to work in the office, as provided by the RFB Ordinance 947/2012.

- Factor 7-Internal factors influencing the work: Segregated in a single factor the statement on flexibility in working relations, as a confirmed advantage of teleworking.

- Factor 8-External factors influencing work: These are personal indicators that can positively or negatively influence the option for telework. The disadvantage indicator "distraction with domestic chores" was not confirmed as a disadvantage in this study, and the advantage indicator "self-employed" was not confirmed as an advantage, that is, most teleworkers are not able or do not want to work independently (be self-employed).

- Factor 9-Home structure: These are structural indicators of the condition of working at home. The results validate these items as disadvantages of teleworking.

- Factor 10 - Adequacy to teleworking: Segregated in a single factor the statement about the worker's adaptation to telework as an important item to be evaluated separately. In this study, $86.7 \%$ disagreed with the statement of nonadaptation to teleworking, but three respondents did not adapt.

- Factor 11 - Agency structure: The change in organizational structure was seen as a disadvantage originally, but this analysis showed that there were no major changes for the agencies.

- Factor 12 - Training: Lack of training was seen as a disadvantage originally. The analysis showed that $50 \%$ had specific training for telework, but $33.6 \%$ did not have training, which shows that there is still a gap to be developed in order to ensure greater security for the teleworker.

\section{Results of the content analysis}

The content analysis was based on an initial organization of the information collected from the four interviews with managers (which lasted an average of 40 minutes) in order to identify the main advantages and disadvantages of telework as they reported. Subsequently a categorization of the open questions was made. These categories of analysis helped in the results triangulation and inferences. 
The content analysis was used to treat the data collected (BARDIN, 2011). The data were prepared, coded, and categorized to be analyzed. The interview script applied to the 4 managers was divided into the following categories of analysis: a) implementation of telework in the public agency; b) telework selection process; c) advantages and disadvantages of teleworking for the manager and the teleworker; d) advantages and disadvantages of teleworking for the public agency; e) supervision of teleworkers; and f) workers performance evaluation system.

For Serpro and Federal Revenue managers, the deployment of teleworking at the public agency was viewed with some mistrust, as described in the following statements:

There was a first movement of adherence, some employees came in, others were observing how it would be because they were afraid of losing contact with the company. (M1)

They had a very difficult time trying to measure and set goals for employees, but now that they are seeing the potential benefit of teleworking, they are accepting it. (M2)

The lexical selections "fear" and "difficulty" suggest an organizational change that people were not prepared to accept. This corroborates the 2016 Management Report of Serpro (2017), in which the company places teleworking as part of its benefits plan, as an incentive for employees to join the program.

Regarding the teleworking selection process, it was possible to verify that internal openings are announced, listing several selection criteria that focus on the interest and desire to improve performance. There is also a concern with the working conditions, as described in the following statements:

They consulted colleagues in the office who had an interest [in telework], they ranked those who were interested, in a way that the ones with low performance would have the chance to improve by teleworking, and then they created an initial group. (M2)

They received a registration form, [...] asked if the person has a physical disability, asked about socioenvironmental conditions, whether they live alone, if they have a room in their house that can be turned into an office, if there are people living in the "workplace", if you have pets [...]. (M3)

In Serpro (2017), three openings for telework were announced: the first, for 18 positions in 2005; the second, for 50 positions in 2007; and finally, 110 positions in 2012. The agency currently has 87 teleworkers. As for the Federal Revenue Department, in 2014 the agency implemented a pilot project for workers in the activity of analysis and judgment of administrative processes, according to its annual activity report (RECEITA FEDERAL, 2014).

In the perception of the interviewed managers of the two agencies, the advantages identified for the manager and the teleworker were: quality of life and work, productivity, flexible hours, and creation of standardized measurement, as described below:

You gain in the quality of life of the person, you gain in the quality of work because then they can dedicate and give their best work possible. (M1)

For the worker, it is a considerable advantage: it is the adjustment of their health and quality of life; they can make their own schedule. The biggest benefit is when I can create a measurement, and with this measurement, I can assess both colleagues who are teleworking and the others in the office, because the gain in performance is comparable. (M2)

However, in the perception of the managers interviewed, the disadvantages evidenced are non-adaptation, loss of connection with the company, psychological problems, social isolation, and lack of immediate communication - as observed in the discourse:

The disadvantage is that they may not be immediately available, right, there is this aspect of the person being by your side or not. (M4)

Some people were approved and did not adapt [...] they started to show signs of depression because they were isolated in a home environment. [...] They loose some of this emotional bond with the company. This factor should be observed. (M3)

The discourses indicate signs of professional isolation, indicating that the communication and engagement mechanisms used in teleworking must be intensified to bring workers closer to the organization. 
Regarding the main advantages identified for the agency, in the perception of the managers interviewed, are reduction of the cost with the employee; higher productivity; knowing the real demand for work; and less exposure to risks such as stress, violence, and disease, as demonstrated in the following responses:

A point of advantage would be the cost of maintaining the employee at the company's premises [...] There is a tendency for them to produce better at home, and to be less exposed to the risk of burglaries or stress when commuting. (M3)

So, this benefit of knowing the actual demand for work is even more important than the productivity gain pointed out by the colleagues. (M2)

The RFB Ordinance 947/2012, of the Federal Revenue Department (RECEITA FEDERAL, 2012), provides that teleworkers' performance goals should be at least $15 \%$ higher than those for traditional workers. Therefore, for this agency, knowing the real work demand is the greatest benefit, confirming the interviewee's discourse.

In the perception of the Serpro and the Federal Revenue managers interviewed, the main disadvantages for the agency were: problems of technological infrastructure; control of the teleworker; differences in the relationship between traditional workers and teleworkers; and no strategy for bringing the teleworker back to the traditional work, as described in the following answers:

The big question is to create a quick mechanism so that you can get in touch with each other as if the person were in the office company. They have problems accessing some management systems and internal services. (M1)

Teleworking is a lot of work for the management ... for a coworker who went out on telework, I had to use the work of almost two employees only to control the teleworker activity. (M2)

Sometimes you do not have many mechanisms to ... "undo" [the option to become] a teleworker. (M3)

Several managers saw this as a privilege and could not cope with the "jealousy" of people who could not enter this form of work. (M4)

RFB Ordinance $947 / 2012$ provides for project managers to control the activities of the teleworker and the forms of disconnection of this form of work, while in Serpro there is no such instruction.

Regarding supervision, the managers interviewed affirmed that there is little difference in these activities specifically related to teleworkers. The main supervision activities were the appointment of a teleworker project manager, and the obligation to come to Serpro's office every fortnight, according to the following responses:

You can request [the teleworker to come], but this is rare. Their presence is required once a fortnight. (M3) Serpro has a system of performance management, so, it demands that you have a formal plan of work to evaluate during a specific period. Thus, we use this plan to carry out these activities [evaluation] as if the employee were in the company. (M1)

Productivity [...] every area that has an employee in teleworking, there is someone that we called telework project manager, who is responsible for passing the tasks for the employee, supervising the results and assessing the productivity [...]. (M2)

Finally, for the performance assessment, the agencies seek to treat all workers the same. It is clear for the interviewees that there is no difference in the evaluation system applied for the teleworkers, as stated in the following narratives:

[...] [They] are treated equally, the norms on this matter. There is no difference between an employee that is inside the company and one that is doing telework. (M1)

The measurement adopted is the same. They do the same thing. The difference is the target that in the case of teleworking, the performance expected is of 15\% higher [than the performance of the traditional workers], but the work process is identical. (M2) 


\section{DISCUSSION}

The results show that teleworkers consider as the main advantages of the approach, the reduction of costs on commuting and food, safety, less exposure to violence and pollution, privacy, greater interaction with the family, and quality of life, focusing strongly on the workers' individuality. In the aspects related to professional activity the items, autonomy, motivation, productivity, flexible hours, less interruptions, and quality of work, were considered as gains. In this sense, our findings corroborate studies by Costa (2013) and Mello, Santos, Shoiti et al. (2014), who observed better quality of life, autonomy and motivation as advantages of teleworking.

On the other hand, the findings of this research point to disadvantages such as technological infrastructure problems (especially lack of specific training), non-adaptation to telework, loss of connection with the company, professional isolation, lack of immediate communication, loss of status, fear of poor evaluation and lack of recognition, compromising promotion and professional development in the agency. In this sense, our study corroborates the work by Caillier (2012) and De Vries, Tummers and Bekkers $(2017,2018)$ that identified negative effects of teleworking, including demotivation, professional isolation, and less organizational commitment on the days when they worked entirely at home. In addition, it has been observed that domestic chores may hinder work performance, there is a need to raise awareness of the family and there is a temptation to do other jobs independently. These negative aspects constitute points of attention that must be considered in the process of teleworking observing the characteristics of the public agency.

In the research with the managers, the study revealed as advantages of teleworking: saving time, cost reduction, creation of standardized measurements, and the knowledge of the real demand of work. The main disadvantages identified were: difficulty in communication and control of the teleworker, differences in the relationship between the traditional worker and the teleworker, workers who do not adapt, psychological issues, and the teleworker's return to traditional work.

After analyzing the different aspects involved in this research, the results point to a way of developing teleworking practices through two lines of action. First, creating mechanisms that help balance the teleworkers' professional activities and personal life, giving greater attention to the infrastructure, technology, and psychological support. Second, introducing management and control tools that aim to minimize the managers' lack of practice in managing teleworkers, seeking isonomy in recognizing and evaluating them.

\section{FINAL CONSIDERATION}

Public administration has been seeking ways to be more efficient in its various activities. In this context, teleworking has also been adopted to reduce costs, to better use time, and to increase productivity. The evidence obtained in this study, however, is that, despite notable advances, there are still challenges to be overcome in order to reach the full potential of teleworking.

Freitas (2008) points out that there is a state bureaucracy that must be overcome to give rise to new management processes, a situation that cannot be thought only in moments of crisis or institutional restructuring. There are several institutions adopting teleworking, but this issue is still not widespread in state and municipal public agencies.

The limitation of this study lies in the fact that, of the five public agencies contacted, only two of them submitted to the research. Nevertheless, this article points out aspects about teleworking that had not been discussed in the literature. The suggestion for future work is to expand the study to other public agencies and in other states, to have a better understanding of the impacts of teleworking in the Brazilian public administration. 


\section{REFERENCES}

ADERALDO, I. L.; ADERALDO, C. V. L.; LIMA, A. C. Aspectos críticos do teletrabalho em uma companhia multinacional. Cadernos EBAPE.BR, v. 15, n. esp., p. 511-533, 2017.

BARDIN, L. Análise de conteúdo. Lisboa: Ed. 70, 2011.

BARROS, A. M.; SILVA, J. R. G. Percepções dos indivíduos sobre as consequências do teletrabalho na configuração home-office: estudo de caso na Shell Brasil. Cadernos EBAPE.BR, v. 8, n. 1, p. 71-91, 2010.

BOONEN, E. M. As várias faces do teletrabalho. Revista Economia \& Gestão, v. 2, n. 4, p. 106-127, 2008.

BRASIL. Plano Diretor da Reforma do Estado. Brasília, DF: Ministério da Administração Federal e Reforma do Estado, 1995. Available at: <http://www.biblioteca.presidencia.gov.br/publicacoes-oficiais/ catalogo/fhc/plano-diretor-da-reforma-do-aparelho-do-estado-1995. pdf>. Accessed on: Mar. 05, 2018.

BRESSER-PEREIRA, L. C. Reforma do Estado para a cidadania: a reforma gerencial brasileira na perspectiva internacional. São Paulo: Ed. 34, 2008.

CAILLIER, J. G. The impact of teleworking on work motivation in a U.S. federal government agency. The American Review of Public Administration, v. 42, p. 461-480, 2012.

CAILLIER, J. G. Are teleworkers less likely to report leave intentions in the United States federal government than non-teleworkers are? The American Review of Public Administration, v. 43, p. 72-88, 2013.

COOPER, C. D.; KURLAND, N. B. Telecommuting, professional isolation, and employee development in public and private organizations. Journal of Organizational Behavior, v. 23, n. 4, p. 511-532, 2002.

COSTA, I. S. A. Teletrabalho: subjugação e construção de subjetividades. Revista de Administração Pública, v. 41, n. 1, p. 105-124, 2007.

COSTA, I. S. A. Controle em novas formas de trabalho: teletrabalhadores e o discurso do empreendedorismo de si. Cadernos EBAPE.BR, v. 11, n. 3, p. 462-474, 2013

CRESWELL, J. W.; CLARK, V. L. P. Designing and conducting mixed methods research. Thousand Oaks, CA: SAGE, 2017.

DAHLSTROM, T. R. Telecommuting and leadership style. Public Personnel Management, v. 42, p. 438-451, 2013.

DE VRIES, H.; TUMMERS, L.; BEKKERS, V. A stakeholder perspective on public sector innovation: why position matters. International Review of Administrative Sciences, 2017. In press.

DE VRIES, H.; TUMMERS, L.; BEKKERS, V. The benefits of teleworking in the public sector: reality or rhetoric? Review of Public Personnel Administration, v. 28, P. 1-22, 2018.

DUNLEAVY, P. et al. New public management is dead: long live digital-era governance. Journal of Public Administration Research and Theory, v. 16, n. 3, p. 467-494, 2006.

EOM, S. J.; CHOI, N.; SUNG, W. The use of smart work in government: empirical analysis of Korean experiences. Government Information Quarterly, v. 33, n. 3, p. 562-571, 2016.
FARIA, L. J. Nova administração pública: o processo de inovação na administração pública federal brasileira visto pela experiência do "Concurso Inovação na Gestão Pública Federal". In: ENCONTRO DA ASSOCIAÇÃO NACIONAL DE PÓS-GRADUAÇÃO E PESQUISA EM ADMINISTRAÇÃO, 33., 2009, São Paulo. Anais... São Paulo: Anpad, 2009.

FREITAS, S. R. Teletrabalho na administração pública federal: uma análise do potencial de implantação na diretoria de marcas do INPI. 120f. Thesis (Doctor Degree in Administration) - Escola Brasileira de Administração Pública e de Empresas, Fundação Getulio Vargas, Rio de Janeiro, 2008.

GASPAR, M. A. et al. Teletrabalho no desenvolvimento de sistemas: um estudo sobre o perfil dos teletrabalhadores do conhecimento. Revista Ciências Administrativas, v. 17, n. 3, p. 1029-1052, 2014

HISLOP, D. et al. Variability in the use of mobile ICTs by homeworkers and its consequences for boundary management and social isolation. Information and Organization, v. 25, n. 4, p. 222-232, 2015.

INSTITUTO BRASILEIRO DE GEOGRAFIA E ESTATÍSTICA - IBGE. Censo Demográfico 2010. Rio de Janeiro: IBGE, 2010. Available at: <http://biblioteca.ibge.gov.br/visualizacao/periodicos/99/cd_2010_ resultados_gerais_amostra.pdf>. Accessed on: Sept. 04, 2016.

MELLO, A. A. A. et al. Teletrabalho como fator de inclusão social e digital em empresas de call center/contact center. Revista de Administração da Universidade Federal de Santa Maria, v. 7, n. 3, p. 373-388, 2014

NILLES, J. Telecommunications and organizational decentralization. IEEE Transactions on Communications, v. 23, n. 10, p. 1142-1147, 1975.

NILLES, J. M. Making telecommuting happen: a guide for telemanagers and telecommuters. New York: Van Nostrand Reinhold, 1994.

NOGUEIRA, A. M.; PATINI, A. C. Trabalho remoto e desafios dos gestores. Revista de Administração e Inovação, v. 9, n. 4, p. 121 152, 2012.

NOHARA, J. J.; ACEVEDO, C. R.; RIBEIRO, A. F.; SILVA, M. M. O teletrabalho na percepção dos teletrabalhadores. Revista de Administração e Inovação, v. 7, n. 2, p. 150-170, 2010.

PÉREZ, M P.; SÁNCHEZ, A. M.; LUIS CARNICER, M. P. Benefits and barriers of telework: perception differences of human resources managers according to company's operations strategy. New Technology, Work and Employment, v. 22, n. 3, p. 208-233, 2007.

RABELO, A. Quais as vantagens e desvantagens do teletrabalho e das organizações virtuais na era da informação? Revista de Administração FACES Journal, v. 1, n. 1, p. 61-67, 2000.

RECEITA FEDERAL. Portaria RFB no 947, de 20 de abril de 2012. Regulamenta a experiência-piloto de Teletrabalho no âmbito da Secretaria da Receita Federal do Brasil. Diário Oficial da União, Brasília, DF, 2012. Available at: <http://normas.receita.fazenda. gov.br/sijut2consulta/link.action?visao=anotado\&idAto=37824>. Accessed on: May 01, 2017. 
RECEITA FEDERAL. Relatório Anual de Atividades da Receita Federal - 2014. 2014. Available at: <https://idg.receita.fazenda. gov.br/publicacoes/relatorio-anual-de-atividades/receita_federal_ relatorioatividades-1.pdf>. Accessed on: May 01, 2017.

RECEITA FEDERAL. Quantitativo de cargos. 2018. Available at: $<$ https://idg.receita.fazenda.gov.br/sobre/servidores/quantitativode-cargos>. Accessed on: Apr. 22, 2017.

ROCHA, C. T. M.; AMADOR, F. S. O Teletrabalho: Conceituação e Questões para Análise. Cadernos EBAPE.BR, v. 16, n. 1, p. 154-162, 2018.

SAKUDA, L. O.; VASCONCELOS, F. C. Teletrabalho: desafios e perspectivas. Organizações \& Sociedade, v. 12, n. 33, p. 39-49, 2005.

SERVIÇO FEDERAL DE PROCESSAMENTO DE DADOS - SERPRO. Relatório da Administração 2016. 2017. Available at: <http:// www.serpro.gov.br/menu/quem-somos/transparencia1/contas_ anuais/2016/relatorio-da-adminstracao-29-03-2017.pdf>. Accessed on: Apr. 22, 2017.

SILVA, A. M. S. A aplicação do teletrabalho no serviço público brasileiro. In: CONGRESSO INTERNACIONAL DE DIREITO E CONTEMPORANEIDADE, 3., 2015, Santa Maria. Anais... Santa Maria, RS: [s.n.], 2015.
SOARES, A. Teletrabalho e comunicação em grandes CPDs. Revista de Administração de Empresas, v. 35, n. 2, p. 64-77, 1995.

SOCIEDADE BRASILEIRA DE TELETRABALHO E TELEVENDAS - SOBRATT. Aprovada resolução que regulamenta o teletrabalho no Poder Judiciário. 2016 Available at: <http://www.sobratt.org.br/index. php/14062016>. Accessed on : June 21, 2016.

TREMBLAY, D. G. Organização e satisfação no contexto do teletrabalho. Revista de Administração de Empresas, v. 42, n. 3, p. 54-65, 2002.

TROUP, C.; ROSE, J. Working from home: do formal or informal telework arrangements provide better work-family outcomes? Community, Work \& Family, v. 15, n. 4, p. 471-486, 2012.

VILLARINHO, K. P. B.; PASCHOAL, T. Teletrabalho no Serpro: pontos positivos e negativos e relações com desempenho profissional, bem-estar e contexto de trabalho. In: ENCONTRO DA ASSOCIAÇÃO NACIONAL DE PÓS-GRADUAÇÃO E PESQUISAS EM ADMINISTRAÇÃO, 40., 2016, Costa do Sauípe. Anais... Costa do Sauípe, BA: Anpad, 2016.

Fernando Filardi

ORCID: https://orcid.org/0000-0002-9333-0871

Post-Doctoral in administration from University of São Paulo; Professor and researcher at the Masters in Administration Program of IBMEC, Rio de Janeiro-RJ, Brazil. E-mail: fernando.filardi@ibmec.edu.br

Rachel Mercedes P. de Castro

ORCID: https://orcid.org/0000-0002-6396-3280

Masters in administration from IBMEC, Rio de Janeiro - RJ, Brazil. E-mail: rampc2003@gmail.com

Marco Tulio Fundão Zanini

ORCID: https://orcid.org/0000-0002-2653-7151

Doctor in Management from the University Magdeburg - Germany; Professor and researcher of the Masters in Administration Program of FGV EBAPE, Rio de Janeiro - RJ, Brazil. E-mail: marco.zanini@fgv.br 